\title{
"ИГРОКИ" НА "АРЕНАХ»: АНАЛИЗ ВЗАИМОДЕЙСТВИЙ В ГОРОДСКИХ ЛОКАЛЬНЫХ КОНФЛИКТАХ (СЛУЧАЙ САНКТ-ПЕТЕРБУРГА И МОСКВЫ)
}

В статье предпринят сравнительный анализ полей городской политики в Москве и Санкт-Петербурге. Основной для анализа стала уникальная база данных конфликтов, произошедших в этих городах в 2012-2014 гг,, содержащая информацию о взаимодействиях всех участников согласования интересов в ходе реализации спорных градостроительных проектов, а также материалы интервью с экспертами и лидерами протестных инициатив. Опираясь на теорию полей стратегического действия и стратегическую интеракционную перспективу, авторы рассматривают московскую и петербургскую городскую политику как отдельные поля, в которых формируются и развиваются особые конфигурации интерактивных арен, гражданские инфраструктуры и отношения между игроками-участниками политического процесса. Московское поле городской политики характеризуется наличием крупных федеральных градостроительных проектов, большим «весом» городских чиновников в качестве контрагентов протестующих, тогда как Санкт-Петербург обладает сравнительно меньшим городским бюджетом и вынужден привлекать бизнес-инвесторов для будущего развития городских территорий. В совокупности, эти характеристики городов определяют конфигурации возникающих в них конфликтных взаимодействий. Проанализировав динамику взаимодействий игроков-участников градостроительных конфликтов, мы выделили следующие сценарии их развития: «отчаянный горожанин», «экспертный бой», «сильный нападающий», «слабый нападающий», «фрагментация интересов» и «широкий альянс». Данные сценарии предполагают разные

Анна Александровна Желнина- к.социол.н., PhD in Sociology, ст.н.с., Социологический институт РАН - филиал ФНИСЦ РАН, Санкт-Петербург, Россия. Электронная почта: azhelnina@gmail.com

Елена Валерьевна Тыканова- к.социол.н., ст.н.с., Социологический институт РАН- филиал ФНИСЦ РАН, Санкт-Петербург, Россия. Электронная почта: elenatykanova@gmail.com 
форматы выстраивания альянсов игроков (или указывают на отсутствие таких коалиций), различия в выборе «формальных» и/или «ситуативных» арен взаимодействия, разную степень радикальности действий игроков. Сценарии также различаются по вероятности исходов конфликта. Так, стратегии «широкий альянс» и «слабый нападающий» предоставляют больше шансов на удовлетворение требований протестующих против спорного проекта. Выделенные сценарии являются скорее идеальными аналитическими типами, тогда как в эмпирической реальности мы нередко наблюдаем сочетание элементов того или иного сценария в каждом отдельно взятом случае.

Ключевые слова: городской локальный конфликт, поле городской политики, стратегическая интеракционная перспектива, игроки, арены

DOI: 10.17323/727-0634-2021-19-2-205-222

Сравнительный подход открывает возможности для понимания особенностей гражданского участия в городской политике. На данный момент нет работ, посвященных сравнению гражданских инициатив и их вклада в развитие территорий в российских городах: большинство публикаций на эту тему касается изучения отдельных случаев (кейс-стади) или же выработки методологических рекомендаций по урегулированию конфликтов (см.: Желнина, Тыканова 2019). В этой статье мы заполняем этот пробел и анализируем состояние полей городской политики в Москве и Петербурге на основании уникальной базы данных городских конфликтов в 2012-2014 гг. Москва и Петербург выбраны для подробного анализа потому, что именно здесь исследователи зафиксировали наибольшее число городских конфликтов (Семенов 2019); кроме того, оба города являются субъектами федерации, что делает их сравнимыми.

Анализ опирается на теории стратегического интеракционизма, в частности, на теорию полей стратегического действия и стратегическую интеракционную перспективу. Московская и петербургская политика рассматриваются как отдельные поля, в которых сформировались и развиваются свои конфигурации игроков (участников политического процесса) и арен (площадок их взаимодействия). Несмотря на важные различия между полями городской политики в двух городах, выделяются и сходства, обусловленные тем, что оба входят в состав политического поля более высокого уровня - российской политики, с ее юридическими и культурными характеристиками. Далее идентифицируется ряд сценариев, по которым могут развиваться городские конфликты.

\section{Поля городской политики}

Теория полей стратегического действия (Fligstein, McAdam 2011) предлагает применить понятие «поля», предложенное Пьером Бурдье, 
для анализа коллективного действия. Поля, порядки среднего уровня (mesolevel orders) и «базовые единицы коллективного действия в обществе» (Fligstein, McAdam 2011:3) структурируют индивидов в социальном пространстве и задают направленность их деятельности, которая ориентирована на получение преимущества в поле. Поля стратегического действия, как и поля в теории Бурдье, не имеют жестких границ; организованы как матрешка, и могут входить в состав полей высшего уровня или распадаться на более «мелкие» поля. Например, общественное движение, участвующее в поле городской политики, может само рассматриваться как поле, когда участники этого движения договариваются о стратегии и лидерстве между собой. В отличие от привычных терминов, таких как «городской политический режим», понятие «поле городской политики» призвано отразить многообразие участников взаимодействий и динамику их отношений друг с другом. Мы определяем городской конфликт как ситуацию, в которой разные игроки публично озвучивают свои требования по поводу будущего городской территории. Их требования вступают в противоречие с озвученными планами и требованиями других игроков.

Стратегическая интеракционная перспектива (Jasper, Duyvendak 2015) уделяет большее внимание мотивациям конкретных игроков и их восприятию ситуации. Игроки взаимодействуют друг с другом, преследуя определенные стратегические цели, но они также устанавливают приоритеты, выбирают стратегии, и справляются с внутренними противоречиями. Почти все политические игроки- составные игроки, которым для совместного действия нужна групповая солидарность. Поэтому коллективные игроки сами могут быть аренами стратегического действия.

Арены и поля- родственные понятия, описывающие конкурентные отношения игроков по поводу какого-либо проекта или решения. Для концептуальной ясности имеет смысл разделить порядок среднего уровня (поле) и микросоциальные порядки, арены. Арены- наблюдаемые места и ситуации, с которыми ассоциируются правила поведения и ожидаемые результаты взаимодействия, в то время как поле- это более абстрактный уровень социальной организации. Например, ареной можно назвать заседание городского совета, которое проходит в конкретный день в конкретном помещении, где действуют правила поведения, иерархии, и на котором могут приниматься определенные решения. Конкретные взаимодействия на аренах «собираются» в поля стратегического действия.

Арены, на которых разворачивается взаимодействие игроков, могут быть связаны друг с другом (Jasper 2021:7) и являться частью формальной системы (как суды разного уровня), или связаны самими игроками, которые, переходя из одной интерактивной арены, «приносят» с собой багаж взаимоотношений и свое стратегическое видение. Одна арена и результат в ней может стать ступенькой к успеху в связанных аренах: например, успешный рекрутинг сторонников на публичных слушаниях по поводу 
спорного проекта может стать платформой для создания активистских сообществ, которые продолжат борьбу в судах.

Общественные кампании, происходящие на этих аренах, имеют больший спектр результатов, чем отклонение или реализация проекта под вопросом, но в статье мы рассматриваем именно эти два типа результатов. Более долгосрочные последствия, влияние взаимодействия на социальные, политические и культурные измерения остаются за кадром. Важно понимать, что поражение в конкретном конфликте может стать ступенькой к последующим победам, повлиять на конфигурацию и правила функционирования самого поля городской политики, задавая новые правила игры в нем.

Пытаясь воздействовать на решения, принимаемые на различных аренах, игроки сталкиваются со стратегическими дилеммами: например, им приходится выбирать степень радикальности действий. Фрэнсис Фокс Пивен и Ричард Клауард предположили, что агрессивные, разрушительные для системы действия со стороны протестующих более эффективны (Piven, Cloward 1979). Позже исследования показали, что эффективность каждого действия, включая агрессивность, зависит от обстоятельств и действий других игроков. Настойчивость и радикализация могут привести к успеху во враждебно настроенной среде, если другие игроки в целом готовы поддержать инициативу протестующих, но радикализация со стороны последних может иметь эффект бумеранга и нанести делу вред (Amenta 2006). История взаимодействий, предыдущие поражения и победы на других аренах, влияют на возможности игроков преуспеть в будущем. Их отношения друг с другом, опыт, память о предыдущих конфликтах становятся «багажом», который может помочь или помешать (Jasper et al. forthcoming). Поэтому нам важно изучать последовательности взаимодействий на разных аренах, с особым вниманием к промежуточным исходам этих взаимодействий.

В статье мы пытаемся совместить микро- и мезоуровни анализа, рассматривая в совокупности ход интеракций на различных, часто связанных, аренах, учитывая мезоуровень - состояние поля городской политики (Zhelnina 2020) в конкретном регионе.

\section{Методика исследования и особенности данных}

Для реконструкции особенностей полей городской политики использовалась база данных городских конфликтов в 2012-2014 гг. в Москве и Петербурге (88 случаев, по 44 в каждом городе). Тематически конфликты касались уплотнительной застройки, вырубки зеленых насаждений, реконструкции и сноса зданий, строительства дорог. Для каждого из случаев создавалась учетная карточка, где фиксировались эпизоды взаимодействия, характер арен, состав участников, промежуточные результаты каждого из эпизодов. Отбор конфликтных случаев и материалов об их развитии 
осуществлялся на основе публикаций в СМИ, содержащихся в базе данных «Мой Интегрум», с учетом следующих критериев: состав участников (условие- участие в конфликте горожан и/или профессиональных активистов); локация проекта (в пределах Москвы и Петербурга или на их границе); наличие информации о конфликте в СМИ; наличие исхода конфликта (отмена, изменение или реализация проекта без изменений).

Используемый метод имеет ряд ограничений, которые учитывались при формулировке выводов. В частности, при опоре на базу данных СМИ для отбора кейсов неизбежна проблема асимметрии освещения конфликтов: этот инструментарий фиксирует только те случаи, которые по какой-то причине оказались в поле зрения редакций. Связанное ограничение- избирательное представление эпизодов взаимодействия в СМИ. Частично мы компенсируем это, используя данные личных интервью с участниками событий. Следующее ограничение метода-сравнительная автономность каждого из кейсов в базе. Как отмечалось выше, история предыдущих конфликтов и отношений между игроками в поле городской политики влияет на протекание последующих эпизодов. Однако специфика фиксации данных в наших учетных карточках не позволяет установить прямые связи между событиями «внутри» конфликта и предшествующими ему сюжетами. Этот важный контекст часто проявляется в интервью.

\section{Поля городской политики в Москве и Санкт-Петербурге}

Московская и петербургская городская политика-два разных поля с разными конфигурациями интерактивных арен, гражданскими инфраструктурами и отношениями между игроками. Эти поля схожи, поскольку являются частью более высокого уровня - российской политики с ее юридическими и культурными особенностями. Однако нам удалось идентифицировать и различия, проанализировав распределение конфликтных случаев в двух городах по ряду критериев. Города различаются по тематике проектов, вызывающих разногласия, что является индикатором особенностей городской политики и проблематизации проектов на уровне городской публичной сферы. Для Петербурга характерна проблема уплотнительной застройки (16 случаев, в Москве-6). Одно из возможных объяснений этой разницы- особенности развития городских территорий. К 2012-2014 гг. в Москве осталось меньше потенциально доступных «Пятен» под застройку, чем в Петербурге. Вопросы инфраструктуры, в частности транспортной, при этом вызывают больше протестов в Москве (8 случаев, Петербурге- 3). Это можно объяснить большим бюджетом Москвы и доступом к федеральным проектам. Демонтаж/снос строений, угрозы зеленым насаждениям представлены в Москве и Петербурге практически одинаково (по 14 случаев в каждом городе- сносы, 8 и 11 случаев- зеленые зоны). Оспаривать снос зданий в Москве сложнее: 
большая часть таких проектов была реализована. В Петербурге все спорные проекты, связанные с угрозой зеленым насаждениями, отклонены.

Эффективность реализации спорных городских проектов в двух городах различается. Половина отобранных случаев в Петербурге окончилась отменой проекта и отказом от запланированной трансформации территории (22 кейса), в остальных случаях - проект реализован без изменений (14) или с изменениями (8). В Москве же ситуация практически зеркальная: отказом от реализации проекта закончились 14 случаев, в десяти случаях проект модифицирован, и 20 проектов были реализованы в изначальном виде. Число случаев не позволяет нам говорить о статистической значимости этих цифр, однако они выявляют интересный паттерн, создающий пространство для интерпретации и более внимательного изучения.

Таблицьа 1

\section{Сравнение результатов конфликтов в зависимости от контрагента}

\begin{tabular}{|c|c|c|c|c|c|c|}
\hline Исход & \multicolumn{2}{|c|}{ 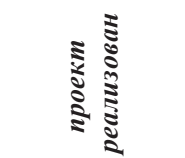 } & \multicolumn{2}{|c|}{ 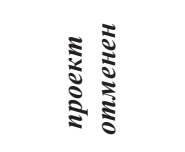 } & \multicolumn{2}{|c|}{ 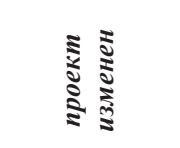 } \\
\hline Адресат & Мск & СПб & Мск & СПб & Мск & СПб \\
\hline Чиновники & 13 & 2 & 5 & 6 & 5 & 5 \\
\hline Бизнес & 5 & 9 & 5 & 15 & 5 & 3 \\
\hline Религиозные организации & 2 & 2 & 1 & 1 & - & - \\
\hline Другое & - & 1 & 3 & - & - & - \\
\hline
\end{tabular}

Учет статуса стороны, продвигающей реализацию проекта, также проливает свет на характеристики полей городской политики в двух столицах (табл. 1). В Москве спорными проектами занимались в основном чиновники (23 случая из 44), а в Петербурге-представители бизнеса (27 случаев из 44). Мы также можем делать предположения о «весе» игроков, продвигающих проект, исходя из сопоставления исходов в этих случаях. Протест против проектов, лоббируемых чиновниками, имеет меньше шансов на успех в Москве: 13 таких проектов реализованы без изменений, пять отменены и столько же подвергнуты модификациям. Московский эксперт подтверждает эту тенденцию:

У нас застройщики, как правило, гораздо лучше себя ведут, чем городские структуры. Вот у нас там вот дом строят, где краны большие; там тоже застройщики приходили в совет депутатов, опять что-то обсуждали. 
<..> По крайней мере они приходят, с ними можно общаться, а город вообще не хочет ничего (И1).

В Петербурге только два проекта, где адресатом протеста были чиновники, реализованы, шесть отменены и пять модифицированы. В случаях, где контрагентом выступали представители бизнеса, Петербург также демонстрирует большую эффективность протестов: 15 проектов отменены, девять реализованы полностью и три с модификациями. В Москве такие проекты имели равные шансы привести к одному из трех исходов (по пять случаев в каждой из категорий).

Различия в результативности протестов в Москве и Петербурге можно объяснить разным положением чиновников в двух городах, объемом доступных им ресурсов и рычагов влияния. В частности, в московских интервью с участниками конфликтов и экспертами тема личной финансовой заинтересованности чиновников в продвигаемых ими проектах возникает регулярно. Нельзя не отметить разницу в бюджетах городов: близость федерального бюджета и узлов принятия решений в Москве сказывается на масштабности реализуемых там проектов. Опытная московская активистка так охарактеризовала известный феномен «сращивания» бизнес-структур с городскими властями, отмечая, что такая конфигурация отношений игроков полностью блокирует взаимодействие с протестующими:

Большой девелопер [может] быть вообще срощенным с кем-то. Но тут у нас [в конфликте] вообще маленький, частный, они только один дом построили. Но просто они как бы вышли на этого [чиновника] и смогли занести-значит, всё (И2).

В Петербурге городской бюджет меньше, и главным двигателем трансформации территорий являются бизнес-структуры. Личную заинтересованность чиновников в таких проектах исключать нельзя, однако в интервью с петербургскими активистами и экспертами эта тема присутствует не так явно, как в Москве. Хотя речь о прозрачности городских властей в Петербурге не идет (губернатор Полтавченко был известен своей непубличностью), интервью демонстрируют некоторый опыт медиации с горожанами и общественниками через ответственных вице-губернаторов и советы. Например, опытный активист-градозащитник отмечает важность потенциально открытых к диалогу игроков в петербургской администрации:

Тогда были вице-губернаторы, они были разные, но вот когда появился Албин, эти вещи [взаимодействие с градозащитниками] стали опять возможны, потому что он занимался именно, ему было важно выслушивать точку зрения. Он мог поступить не в нашу пользу, но выслушать и дать возможность пообщаться, и послушать кто, кому, что сказал, для него было важно (ИЗ).

Сам факт наличия интерактивной арены, созданной по инициативе сильного игрока, открывает для протестующих некоторые возможности. 
Даже если вице-губернатор «мог поступить не в нашу пользу», общение и озвучивание позиций помогало избежать полного тупика.

Следующий паттерн - комбинации арен, где разворачивается взаимодействие по поводу спорного проекта. Существуют ситуативные арены, которые участники процесса, в том числе протестующие, могут создавать по мере необходимости; к ним мы относим арены уличной политики- митинги, «сходы», общение возмущенных граждан с чиновниками во дворах и подобные эпизоды, которые не являются частью формально зафиксированных инфраструктур гражданского участия. Горожане имеют сравнительно бо́льшую свободу в инициировании и использовании таких арен. Также участникам конфликта доступен спектр формальных арен: предусмотренных законодательством платформ разрешения конфликтов и принятия решений, за которыми закреплены определенные функции и решения; например, судебные заседания, публичные слушания, заседания тематических комитетов. Большая часть рассмотренных нами случаев развивалась поочередно как на ситуативных, так и на формальных аренах. В Москве активисты чаще, чем в Петербурге, обращаются только к одному типу арен (только формальные - 11 случаев, только ситуативные- девять случаев).

Из 11 случаев, когда москвичи пытались опротестовать проект исключительно на формальных аренах, семь не привели к успеху. Сочетание разных форматов (ситуативные и формальные арены) с одинаковой частотой приводило к успеху и поражению протестующих (в шести случаях проект отменен, в шести реализован, и в трех- видоизменен). Схожим образом в Петербурге чередование ситуативных и формальных арен стало самой эффективной стратегией. Отчасти эти данные перекликаются с дилеммой радикализации: использование только формальных арен редко связано с радикализацией и демонстрацией бурного несогласия, в отличие от ситуативных арен уличной политики. При этом демонстрация настойчивости на уличных аренах может быть полезна для эффективности протеста. Сочетание арен разного типа позволяет игрокам максимизировать задействованные инструменты участия и продемонстрировать серьезность своего настроя, WUNC displays: единство, достоинство, многочисленность и настойчивость (Tilly 2008).

Протестующие выбирают те или иные конфигурации арен по разным причинам. Одна из них - накопленный опыт гражданского участия, связи и обмен знаниями с другими участниками (политиками, журналистами, юристами). Мы не можем реконструировать мотивации игроков на основании только базы профилей конфликтов, для этого необходимо обратиться к интервью. База позволяет нам увидеть конфигурации и альянсы игроков, выступающих за и против оспариваемых проектов, раскрыть некоторые особенности полей городской политики в Москве и Петербурге.

В Москве жители оспариваемых территорий часто выступают самостоятельно, не привлекая на свою сторону других игроков (девять случаев). 
С такой же частотой жители объединяли усилия с представителями политических партий или депутатами. Возможно, такая особенность является индикатором сравнительно слабого развития гражданских инфраструктур в городе (Желнина, Тыканова 2019): жителям могут быть недоступны или неизвестны организованные и устойчивые активистские сети и организации, которые нередко подключаются к городским конфликтам в Петербурге. Мы отметили участие профессиональных активистов в семи петербургских конфликтах, и такое же число конфликтов привлекло представителей партий и депутатов. Инициирование оспаривания городских территорий опытными активистами без привлечения обычных горожан характерно именно для Санкт-Петербурга, хотя представлено и в Москве. Эту особенность можно интерпретировать как свидетельство большего развития и активности гражданских инфраструктур в Петербурге.

\section{Сценарии и исходы взаимодействия В городских конфликтах}

В отличие от статистического анализа, перед которым стоит задача идентификации предикторов успеха или поражения конкретной общественной кампании, мы не делаем жестких выводов о факторах успеха гражданских протестов. Вместо этого мы определяем сценарии, при которых горожанам сложнее или проще маневрировать в поле городской политики. Анализ показал, что некоторые характеристики конфликта могут задавать направление взаимодействий, делать выбор определенных арен более предпочтительным, мотивировать радикальность участников. Идентифицировав ряд таких парадигмальных критериев, мы выделили следующие сценарии конфликтных взаимодействий по поводу оспариваемых городских территорий.

\section{Отчаянный горожанин}

Для данного сценария характерна эмоциональная, но запоздалая мобилизация горожан в ответ на информацию о градостроительной инициативе. Граждане, не имеющие активистского опыта и не знакомые с инструментами гражданского участия, устраивают митинги и сходы, пишут жалобы в инстанции, пытаясь остановить нарушивший их покой проект, но не всегда обеспечивают долгосрочность своего протеста.

Например, стремительный снос Северного рынка в Петербурге мотивировал арендаторов выйти на акции протеста, однако это не остановило снос. Подобный случай сноса рынка- у станции метро «Выхино» в Москве- также вывел на улицу предпринимателей и местных жителей, однако их акции привели к обратному эффекту: вызвали обеспокоенность представителей мэрии, которые с удвоенной силой принялись за реализацию проекта. В случае с рынками блиц-снос и невозможность опротестовать решение являются частью московской политики по реорганизации торговых 
пространств и строительству транспортно-пересадочных узлов, которым такие пространства часто мешают. Стремительная реализация проектов помогает городским властям блокировать способность «противника» сопротивляться. Стремительность может приводить к обратному эффекту, вызывая шок и эмоциональное сопротивление горожан. Так нередко происходит в случаях уплотнительной застройки, при сносе или возведении новых зданий в пространствах повседневного пользования горожан.

Эмоциональный стимул действовать редко бывает достаточным условием устойчивого и успешного участия горожан в конфликте. Например, проигрышем горожан закончились непродолжительные конфликты по поводу застройки на Рязанском проспекте, строительства магазина на Южнобутовской улице в Москве, а также пикетирование горожанами азербайджанского ресторана «Тебриз» на периферии Санкт-Петербурга. Неопытные горожане пытаются протестовать при помощи известных им методов (жалоб, пикетов, митингов и сходов), ожидая быстрой реакции. Когда таковой не происходит, разочарование и непонимание, как действовать дальше, могут привести к торможению протеста. В такой ситуации важна поддержка или контакт с более опытными активистами или другими игроками, которые могут подсказать направление.

Иногда эмоциональная мобилизация «отчаянных горожан» становится началом настойчивой и эффективной кампании. Причины, по которым некоторые эмоциональные поводы развиваются в длительные кампании, кроются в микро-интеракциях участников. Лидеры и наличие связей между потенциальными активистами становятся основой для настойчивого и интенсивного протеста, разворачивающегося на разнообразных аренах. Примеры таких протестов- сопротивление сносу кинотеатра «Ленинград» на территории Мемориально-паркового комплекса героев Первой мировой войны, протест против строительства храма на улице Сухонской в долине реки Яуза в Москве.

Еще один фактор, влияющий на шансы «отчаянных горожан» преуспетьхарактеристики других потенциально заинтересованных игроков. Сценарий «отчаянный горожанин» может привести к успеху горожан, если они «играют» против слабого игрока «за». Например, публичные акции горожан против строительства продуктового магазина на ул. Туристской в Петербурге оперативно привели к отмене запланированного проекта. Больше шансов у горожан, когда им удается привлечь в коалицию сильного игрока-чиновника, политика, депутата или известную персону. Успех горожан в борьбе против строительства многоэтажных домов на ул. Маршала Новикова в Петербурге можно объяснить готовностью губернатора прислушаться к мнению протестующих. В Москве угроза вырубки сквера в районе Спиридоньевского и Большого Козихинского переулков привела к объединению усилий горожан с популярными представительницами шоу-бизнеса: телеведущей Татьяной Лазаревой и актрисой Татьяной Догилевой, и это повлияло на успешность 
разрешения конфликта. Причины, по которым сильные игроки могут занимать сторону протестующих или поддерживать проект многообразны, их можно выяснить только на микроуровне анализа. Мы предполагаем, что сильные игроки могут иметь сложные отношения друг с другом и использовать поводы, создаваемые «отчаянными горожанами» для выяснения этих отношений, или же они ориентируются на более широкий спектр интересов, ценностей и целей, которые резонируют с одной из сторон конфликта.

\section{Экспертный бой}

Альтернативный «отчаянным горожанам» сценарий предполагает участие опытных активистов и экспертов, которые ведут борьбу на формальных аренах, не используя ресурс народного недовольства на ситуативных аренах. Мы называем этот сценарий «экспертный бой». Плюс такого сценария- из него исключен «эффект радикала», который может помешать активистам заручиться поддержкой чиновников. Опытные активисты и их контрагенты могут говорить на одном языке, во многих случаях знакомы друг с другом, что делает их взаимодействие более гладким. Минусы сценария- отсутствует важный рычаг давления на власти, эмоциональная мобилизация горожан. По сценарию «экспертного боя» развивались конфликты вокруг строительства ЖК «Баркли Резиденс» у Донского монастыря, сноса доходного дома Прошиных, разрушения в ходе «реставрации» палат Киреевского в Москве, а также строительства ЖК на наб. Лейтенанта Шмидта в Петербурге. В последних двух случаях профессиональные активисты задействовали и ситуативные арены: сценарии «экспертный бой» и «отчаянный горожанин» иногда встречаются в чистом виде, но часто конфликтные случаи включают элементы и того, и другого сценария.

Для успеха «экспертного боя», как и для «отчаянных горожан», важным фактором являются характеристики игрока, продвигающего спорный проект, поскольку некоторые игроки могут задавать рамки взаимодействия и вне сочетания с типом мобилизации горожан. Поэтому мы выделяем два сценария, определяющим признаком которых является сила игрока «за». Под силой подразумевается интегрированность игрока в отношения с другими стейкхолдерами, наличие у него ресурсов (в первую очередь финансовых) и доступа к аренам, где принимаются ключевые решения.

\section{Сильный нападающий}

«Сильный нападающий»-это игрок, хорошо интегрированный в системы управления, он может оказывать влияние на принятие решений (в том числе, участвуя во взаимодействиях на непубличных аренах), имеет в распоряжении полезные ресурсы, которыми обменивается с другими ключевыми игроками. «Сильный нападающий» контролирует правила игры на аренах, создает/уничтожает арены в соответствии со своими целями. Например, манипуляция доступом на общественные слушания, подмена жителей «массовкой». 
В качестве таких нападающих выступают, например, застройщики, как в Москве, так и в Петербурге. В Москве сильными являются федеральные институты. Например, ФСБ в случае строительства академии ФСБ в долине реки Раменки. В Москве сильным игроком нередко оказываются чиновники городского уровня: мэрия Москвы выступала ключевым оппонентом протестующих, например, в случаях угрозы сноса плавательного бассейна в Лужниках и сноса комплексов домов Привалова в Москве. В Петербурге в качестве «сильного нападающего» часто выступают крупные застройщики, например, в случае защиты от сноса доходного дома Лялевича, разрушения комплекса зданий в Мытном дворе, реконструкции дома 36 по улице Мира. «Сильным нападающим» может являться РПЦ, которая активно занимается строительством храмов, нередко занимая под эти цели зеленые зоны и другие территории общественного пользования. Когда контрагентом протестующих выступала РПЦ, им не удавалось добиться успеха: так произошло со строительством храма Святого Александра Невского в сквере около дома 10 по ул. Мневники, капитальной застройкой парка в долине реки Чермянка в Москве, строительством храма в Рождественском сквере на 6-й Советской улице в Петербурге.

Успешное противостояние сильному нападающему возможно, но сильно затруднено и требует большей креативности и настойчивости со стороны протестующих. В таких случаях «отчаянные горожане» редко могут рассчитывать на успех, если они не опираются на хорошо развитые гражданские инфраструктуры- активистские сети и ресурсы. Иногда такие сложные случаи в сочетании с эмоциональной мобилизацией могут дать толчок для постепенного создания и укрепления гражданских инфраструктур.

\section{Слабый нападающий}

В сценарии, где основной игрок «за» не имеет прямого доступа к ключевым аренам или ценных для обмена ресурсов, протестующие имеют больше возможностей для маневра. В сценарии «слабый нападающий» чиновники не так сильно заинтересованы в проекте или не слишком связаны с игроком «за» проект предыдущими отношениями и обязательствами. Например, попытка мормонов построить церковь Иисуса Христа Святых последних дней на пр. Хошимина в Петербурге натолкнулась на результативное сопротивление горожан; проект возведения магазина на месте детской площадки на пр. Науки в Петербурге; попытки монтажа мансардных надстроек на Большой Молчановке 17 и Фрунзенской набережной 12 в Москве. Три последних случая продвигались предпринимателями, а чиновники заняли нейтральную или переговорную позицию.

Даже в сценарии со сравнительно слабым нападающим протестующие должны действовать активно и настойчиво, чтобы добиться успеха. В случае со строительством магазина на пр. Науки горожане предпринимали радикальные меры: блокировали работу строительной техники, пере- 
крывали автомобильное движение. Этим они привлекли к себе внимание сильного игрока, вице-губернатора. Хотя мобилизация произошла поздно (когда строительство уже началось), их радикальные действия привели к результату. Как и в других подобных случаях, для полного понимания ситуации необходима информация о процессах на микроуровне, о конкретных участниках протеста, отношениях между разными уровнями власти, вовлеченными в процесс.

\section{Фрагментация интересов}

Отношения разных стейкхолдеров друг с другом и то, как конкретный конфликт развивается в контексте этих отношений, лежат в основе сценария «фрагментация интересов». Мы уже упоминали, что сильные игроки, занимая определенную позицию по поводу конкретного конфликта, могут на самом деле преследовать другие цели и задействовать городские конфликты для их достижения. Органы городской власти и управления не монолитны, и иногда мы можем идентифицировать признаки разногласий или конкуренции между разными уровнями и подразделениями структур городского управления. Сценарий «фрагментация интересов» связан с феноменом раскола элит, который создает возможности для протестующих. Однако мы определяем этот феномен более широко: разнообразие целей и интересов имеет место не только среди «элит» или институализированных сильных игроков, но и среди других стейкхолдеров, включая общественные движения. Фрагментация одного из игроков создает возможности для противников (например, мы наблюдали раскол в среде активистов в процессе защиты от сноса дома Прошиных в Москве), в то время как консолидация может затруднить их деятельность- например, в таких случаях, когда застройщик и городское правительство выступают единым фронтом. Немало примеров, когда фрагментация интересов среди сильных игроков открывала возможности для протестующих. Например, отмена переноса Военно-медицинской академии в СанктПетербурге, за которую боролись активисты, может быть связана в том числе с конфликтным политическим взаимодействием элит, когда решение оказалось своеобразным имиджевым жестом одного из крупных игроков, вступившего в должность министра обороны:

Ну, вот как и с Военно-медицинской академией и вот с этим госпиталем [31 больница] мы попали в удачный момент, когда меняли с Сердюкова на Шойгу [одного министра обороны на другого]. И Шойгу нужно было что-то спасти, прийти героем. И вот он спас, значит, Военно-медицинскую академию (И4).

Изменением конфигурации политических элит, а именно сменой главы государства и кабинета министров после президентских выборов 2012 г., можно объяснить возобновление вырубки лесов на реке Сходня 
в Москве. Ранее она была приостановлена лично президентом Медведевым и министром природных ресурсов Трутневым.

\section{Широкий альянс}

Противоположный «фрагментации интересов» сценарий предполагает консолидацию и кооперацию разных игроков - «широкий альянс». К некоторым ситуациям оспаривания градостроительных проектов подключаются разнообразные игроки: от обычных горожан и активистских организаций до партий и комитетов городского правительства. Широкие альянсы часто действуют на разных аренах и проявляют большую настойчивость. Так произошло в случае защиты здания поста централизованного управления станции Лихоборы в Москве, когда активисты и горожане выступили единым фронтом в защиту этого небольшого исторического объекта. Это пример того, как работает хорошо настроенная гражданская инфраструктура. Яркими образцами сценария «широкий альянс» являются объединение усилий (в различных комбинациях) горожан, активистов, депутатов, политиков, известных персон и экспертов в борьбе против реконструкции Ленинского проспекта, строительства площадки для автобусов и паркинга рядом со станцией метро «Пятницкое шоссе», строительства северного и южного дублеров Кутузовского проспекта в Москве, строительства гольф-клуба в Баболовском парке, сноса дома Рогова, попытки сноса Блокадной подстанции в Петербурге.

Представители политических партий, депутаты городских легислатур или Государственной думы, часто являются адресатами жалоб и обращений горожан, однако иногда они становятся ключевыми игроками широких альянсов. Сами партии играют меньшую роль, чем отдельные персоны: например, в Петербурге депутат от Справедливой России Алексей Ковалев, известный градозащитник, является не только сторонником, но и движущей силой многих градозащитных процессов, ключевым звеном в гражданской инфраструктуре города. Схожую позицию занимает «яблочник» Борис Вишневский, а в Москве-Сергей Митрохин.

Иногда процесс наращивания альянсов идет постепенно, по мере развития конфликта, приводя к формированию необходимой гражданской инфраструктуры на будущее. Такие кейсы, даже если не приводят к отмене конкретного нежеланного проекта, могут оказаться парадигмальными, задавая правила игры в будущих сходных конфликтах. Примером может послужить поворотный для московской градозащиты случай успешной борьбы против демонтажа Шуховской башни на Шаболовке:

Федералы в это время попытались схамить с разборкой Шуховской башни. Федералы, ведомство связи. И тут мы ударили по рукам. То есть Шуховская башня просто стоит таким знаком в 14-м году. Но я бы сказал, что после 14-го года покушение на статусные памятники и использование разных видов манипуляций стало в Москве как-то уже не принято (И5). 
Контрагенты горожан и активистов- застройщики, чиновники, политики и эксперты- также могут формировать широкие альянсы. Например, в случае конфликта вокруг строительства Северо-Западной хорды в Москве в альянс сторонников проекта вошли московская мэрия, депутаты Мосгордумы, чиновники департамента транспорта, главы управ районов, по которым предполагалась трассировка магистрали, а также горожане и активисты организации «Умный город».

\section{Заключение}

Опираясь на базу данных о конфликтных случаях, произошедших в 2012-2014 гг. в Санкт-Петербурге и Москве, а также на экспертные интервью, мы в сравнительной перспективе проанализировали поля городской политики. Насколько нам известно, это первая попытка систематического сравнения городских конфликтов в отечественной дискуссии, результатом которой стало аналитическое выделение сценариев развития градостроительных конфликтов с участием горожан и активистов. Мы также выдвинули предположения о взаимосвязи полученных сценариев с исходами конфликтных взаимодействий. Московское поле городской политики характеризуется наличием крупных федеральных градостроительных проектов, бо́льшим «весом» городских чиновников в качестве контрагентов протестующих, тогда как Петербург обладает меньшим городским бюджетом и вынужден привлекать бизнес-инвесторов для будущего развития городских территорий. В совокупности эти характеристики городов определяют конфигурации возникающих в них конфликтных взаимодействий.

Проанализировав динамику взаимодействий игроков-участников градостроительных конфликтов, мы выделили следующие сценарии их развития: «отчаянный горожанин», «экспертный бой», «сильный нападающий», «слабый нападающий», «фрагментация интересов» и «широкий альянс». Сценарии предполагают разные форматы выстраивания альянсов игроков (или указывают на отсутствие таких коалиций), различия в выборе «формальных» и/или «ситуативных» арен, разную степень радикальности действий игроков. Сценарии также различаются по вероятности исходов конфликта. Например, стратегии «широкий альянс» и «слабый нападающий» предоставляют больше шансов на удовлетворение требований протестующих против спорного проекта. Выделенные сценарии являются скорее идеальными аналитическими типами, тогда как в реальности мы нередко наблюдаем сочетание элементов того или иного сценария.

\section{Выражение признательности}

Исследование выполнено за счет гранта Российского научного фонда (проект РНФ № 18-78-10054) «Механизмы согласования интересов в процессах развития городских территорий». 
Редакция благодарит программу «Университетское партнерство» за поддержку и возможность опубликовать данную статью.

\section{Список информантов}

И1: м., муниципальный депутат района Москвы, градозащитник, март 2020

И2: ж., муниципальный депутат района Москвы, градозащитник, март 2020

И3: м., представитель ВООПИиК, Санкт-Петербург, февраль 2020

И4: ж., координатор градозащитной организации, Санкт-Петербург, ноябрь 2019

И5: м., координатор градозащитного движения, Москва, март 2020

\section{Список источников}

Желнина А., Тыканова Е. (2019) Формальные и неформальные гражданские инфраструктуры: современные исследования городского локального активизма в России. Журнал социологии и социиальной антропологии, 22 (1): 162-192.

Семенов А. (2019) Корни травы: паттерны низовой городской мобилизации в России. Соииологические исследования, (12):29-37.

Amenta E. (2006) When Movements Matter: The Townsend Plan and the Rise of Social Security. Princeton: Princeton University Press.

Fligstein N., McAdam D. (2011) Toward a General Theory of Strategic Action Fields. Sociological Theory, 29 (1): 1-26.

Jasper J. M. (2021) Linking Arenas: Structuring Concepts in the Study of Politics and Protest. Social Movement Studies, 20 (2):243-57.

Jasper J., Duyvendak J. W. (eds.) (2015) Players and Arenas. Amsterdam: Amsterdam University Press.

Jasper J., Elliott-Negri L., Jabola-Carolus I., Kagan M., Mahlbacher J., Weisskircher M., Zhelnina A. (forthcoming) Gains and Losses: How Protestors Win and Lose. Oxford: Oxford University Press.

Piven F. F., Cloward R. A. (1979) Poor People's Movements: Why They Succeed, How They Fail. New York: Vintage Books.

Tilly Ch. (2008) Contentious Performances. Cambridge: Cambridge University Press.

Zhelnina A. (2020) Engaging Neighbors: Housing Strategies and Political Mobilization in Moscow's Renovation. New York: CUNY Academic Works. 
Anna Zhelnina, Elena Tykanova

\title{
'PLAYERS' IN 'ARENAS': A STUDY OF INTERACTIONS IN LOCAL URBAN CONFLICTS (A CASE STUdY OF SAINT PETERSBURG AND MOSCOW)
}

\begin{abstract}
This article presents the results of a comparative study of urban political fields in Moscow and Saint Petersburg. The empirical foundation for our analysis is the unique database of urban conflicts that took place in these two cities in 2012-2014, containing the data on the interactions of different parties involved in the negotiations of the contested urban development projects. We also rely on interviews with experts and protest leaders in Moscow and Petersburg. Building on the theory of strategic action fields and the strategic interaction perspective, we analyse Moscow and Petersburg's urban politics as distinct fields, where specific configurations of arenas, civic infrastructures, and relationships among players, participants of the political process, emerge and develop. Moscow's urban political field is characterised by the prevalence of large federal urban redevelopment projects and the notable involvement of city bureaucrats as the adversaries of protesters. Saint Petersburg, with its smaller city budget, is more oriented toward attracting business investors for redevelopment. These features of urban political fields shape the emerging configurations of players and their interactions in two cities. We analysed the interaction dynamics among players in the urban redevelopment-related conflicts and identified several scenarios: 'desperate urbanite', 'expert battle', 'strong assailant', 'weak assailant', 'fragmentation of interests', and 'broad alliance'. These scenarios involve different formats of alliances among players (or lack thereof), the prevalence of different ('formal' or 'situational') arenas, varying levels of assertiveness of players. The scenarios also differ in terms of the possible outcomes of the conflicts. 'Broad alliance' and the 'weak assailant' are associated with higher chances of protesters to succeed. The identified scenarios are ideal analytic types; in reality, elements of different scenarios can coexist in the development of a particular case.
\end{abstract}

Keywords: urban local conflict, urban political field, strategic interaction perspective, players, arenas

DOI: 10.17323/727-0634-2021-19-2-205-222

\footnotetext{
Anna Zhelnina-Cand. Sci. (Sociol.), PhD in Sociology, Senior research associate, Sociological Institute of the RAS - Branch of the Federal Center of Theoretical and Applied Sociology of the Russian Academy of Sciences, St. Petersburg, Russian Federation. Email: azhelnina@gmail.com

Elena Tykanova- Cand. Sci. (Sociol.), Senior research associate, Sociological Institute of the RAS - Branch of the Federal Center of Theoretical and Applied Sociology of the Russian Academy of Sciences, St. Petersburg, Russian Federation. Email: elenatykanova@gmail.com
} 


\section{References}

Amenta E. (2006) When Movements Matter: The Townsend Plan and the Rise of Social Security. Princeton: Princeton University Press.

Fligstein N., McAdam D. (2011) Toward a General Theory of Strategic Action Fields. Sociological Theory, 29 (1): 1-26.

Jasper J. M. (2021) Linking Arenas: Structuring Concepts in the Study of Politics and Protest. Social Movement Studies, 20 (2):243-57.

Jasper J. M., Duyvendak J. W. (eds.) (2015) Players and Arenas. Amsterdam: Amsterdam University Press.

Jasper J., Elliott-Negri L., Jabola-Carolus I., Kagan M., Mahlbacher J., Weisskircher M., Zhelnina A. (forthcoming) Gains and Losses: How Protestors Win and Lose. Oxford: Oxford University Press.

Piven F. F., Cloward R. A. (1979) Poor People's Movements: Why They Succeed, How They Fail. New York: Vintage Books.

Semenov A. (2019) Korni travy: patterny nizovoy gorodskoy mobilizatsii v Rossii [The Roots of the Grass: Patterns of Grassroots Urban Mobilization in Russia]. Sotsiologicheskiye issledovaniya [Sociological Studies], (12):29-37.

Tilly Ch. (2008) Contentious Performances. Cambridge: Cambridge University Press.

Zhelnina A., Tykanova E. (2019) Formal'nye i neformal'nye grazhdanskie infrastruktury: sovremennye issledovaniya gorodskogo lokal'nogo aktivizma v Rossii [Formal and Informal Civic Infrastructure: Contemporary Studies of Urban Local Activism in Russia]. Zhurnal sotsiologii i sotsial'noy antropologii [The Journal of Sociology and Social Anthropology], 22 (1): 162-192.

Zhelnina A. (2020) Engaging Neighbors: Housing Strategies and Political Mobilization in Moscow's Renovation. New York: CUNY Academic Works. 